\author{
JANUSZ MUCHA ${ }^{1}$ \\ AGH University of Science and Technology in Kraków \\ KAMIL ŁUCZAJ \\ Faculty of Administration and Social Sciences \\ University of Information Technology and Management in Rzeszów

\section{Some Remarks on Academic Migration. Introduction ${ }^{2}$}

The second part of this issue of the SM PP is devoted to highly skilled migrants (sometimes called "highly educated migrants"), and particularly to international academic mobility. In this introduction, we would like to outline the mental map on which the authors of four articles conceptualize their discussion. We are talking here about migrations in the Western world, including Central and Eastern Europe, so the Global South is not considered. This is an important limitation, because global flows and waves of migration of academics, engineers, physicians, etc. are intensively increasing (see, e.g., Kim, Wolf-Wendel and Twombly 2011). Bearing in mind that all types of migration are gender sensitive, we should also mention that gender is not a significant variable in all of the authors' research presented in this issue. Ethnicity of the waves of migration is also rarely taken as important in these articles, although the authors do not ignore it.

The authors put their considerations into other general frameworks which are very important for the migration studies in the early decades of the $21^{\text {st }}$ century:

${ }^{1}$ Corresponding author: Janusz Mucha, jmucha@post.pl

2 The authors of this introduction have devoted a book to these issues regarding academics immigrating to Poland over recent decades (Mucha and Luczaj, 2018). It includes many sources which are not quoted here, including the authors' publications on these topics in English and Polish. 
the "class structure" or stratification of the recent waves of migration; specific characteristics of highly skilled and middling migrations; transnationality and transmigrations; diasporas; "brain circulation" and its asymmetry; and return migration.

Flows and waves of international migration have a social structure and stratification: as mentioned, they occur in various ethnic groups, have a strong gender dimension, and class inequalities within them are visible. Internationally mobile academics, and particularly senior researchers and university professors belong to a much larger and ambiguous category of highly skilled migrants (HSMs) at the privileged upper end of the ladder, along with managers, experts, physicians, engineers and other transnational professionals (see Nowicka 2005). At the lower end, we find unskilled or semi-skilled underprivileged migrant labourers. It is also important to consider the point of view: whether we observe the flow from the perspective of the sending or receiving country. Some migrants who are highly educated and skilled in the former have to take low-skilled jobs in the latter after migrating. Moreover, the group of skilled and educated migrants also includes students (at various levels), post-doctoral fellows, nurses, technicians and other mid-level employees, who do not belong to any social elite. Their social practices have already been summed up by the concept of "middling migrants". Many young scholars, mobile or not, have no steady jobs and instead occupy precarious positions. In this part of our issue, we are mostly discussing their experiences.

When analysing the "new social order" which emerged during the 1980s, Anthony H. Richmond divided the migration waves into the two broad (and obviously simplified) categories of "pro-active" and "re-active". The first type, more interesting for us than the second, refers to mobility which is relatively unlimited by institutionalized regulations (even if some always exist). The choices of these migrants quite often concern, for instance, decisions whether to migrate or not, when to do it, where to go, to go alone or with family members (or partners), how long to stay in the receiving country, where to go from this country, whether to maintain strong ties with the sending country or not, etc. (Richmond 1994: 58-60).

Rafael Alarcon, who analysed the privileged, highly educated groups in the assumed global world of "borderless migrants" in the North American context, was of the opinion that they are pro-active in the sense that they usually make most of their own migrating decisions. However, in his opinion, they usually depend on highly institutionalized conditions facilitating their comfort. They have the support of state regulations and strong corporations (including universities), as well as their own economic, social and cultural capital (Alarcon 2007: 243-244).

Research literature in the field of managerial psychology, devoted to pro-active migrants (including academics), distinguishes the "self-initiated" from "assigned" expatriates ("expats"). Location and dependence on institutional frameworks are the criteria of the difference. It seems that self-initiated migrants are more successful (see, e.g., Biemann and Andersen 2010; Doherty, Richardson and Thorn 
2013; Przytuła 2017). According to John Selmer and Jakob Lauring (2012), those scholars who are self-initiated expats are particularly successful if their migration motivations do not involve an intention to "escape" from their former life in the home country.

Let us concentrate, for a moment, on the (already mentioned) category of middling migrants. In every broadly understood occupational group, there are very highly skilled people but also those with mid-level qualifications. Here, some authors discuss young people, from rich but also poor countries, who go abroad for a relatively short period of time, between high school and college or between college and graduate school. During this "gap year", they travel or work, usually below their qualifications. Others put into this category mostly young academics who find employment abroad in research projects, living "from grant to grant". They engage in this kind of migration out of necessity: international spatial mobility is a condition of social mobility within the hierarchy of their occupation in the country of origin or on the global market. Mobility has been, for centuries, an important aspect of the habitus of scholars and artists. We do not know a lot about this category of migrants. Most of the reports are case studies, but they show how difficult this unstable life is, and how challenging it is to maintain "normal" family relations when involved in it (see, e.g., Loacker and Śliwa 2016; Santos 2016).

In Polish literature, the "middling migration" phenomenon came to light only very recently. Krzysztof Jaskułowski has studied the experiences and strategies of Indian employees of international companies located in Wrocław (see, eg, Jaskułowski 2017; Bielewska and Jaskułowski 2017). It is interesting that, in our opinion, the migration motivations of these specialists are similar to those of the so-called "lifestyle migrants" (see, e.g., O’Reilly and Benson 2009; Spalding 2013; Benson 2016; Andrejuk 2017), whose situation will not be analysed in this introduction.

Some aspects of recent international mobility have been, since the 1990s, covered by the concept of "transmigration", closely related to that of "transnationality". Let us quote a synthetic article by Ewa Morawska, one of the leading scholars in the field, on European and American studies on ethnicity and migrations, where the concept of "transnationality" refers to "civic-political belonging, economic activity, social networks and cultural identities of migrants and their descendants, all of which extend across the state borders and unite people and institutions in at least two countries, constructing heterogeneous patterns of multilevel character. [...] Research on these transnational links concerns issues like remittances, sent by migrants to their motherlands in order to keep the households running over there, business investments, international communication and tourism, maintaining bi- or multiculturalism in formal or informal associations, political activity in both the sending and the receiving country, as well as the roots of all these activities and orientations on micro- and macrosocial levels" (Morawska 2009: 11; see also Morawska 2013; Hannerz 1996; Vertovec 2009). Transnationality and 
transmigration are characteristics of social worlds of all the levels on the migration stratification, but the proportion among the upper levels seems to be significant (see Fauser, Voigtländer, Tuncer, Liebau, Faist and Razum 2012: 6-7).

Another important issue raised in the following articles is the dynamics of the concept of "brain drain", very often exploited in analyses of international migrations, particularly between highly developed and relatively peripheral regions, mainly migrations of highly educated specialists. "Brain drain' is a phenomenon in which people of a high level of skills, qualifications, and competence leave their countries and emigrate. One major case of the brain drain happens when students from developing countries studying in the developed countries decide not to return home after their studies" (Baruch, Budhwar and Khatri 2007: 99). The term first appeared in 1963 and initially (unlike nowadays) referred to British academics and engineers emigrating for employment to the U.S. (Hart 2007: 44). Globalization, the increasing significance of transmigration and transnationality, shifts of centres of technology, increasing international collaboration between research centres, and the multidirectional character of migration flows have all demanded new ideas. Concepts like talent flow, brain gain and brain circulation have become more popular (see, e.g., Jałowiecki and Gorzelak 2004, Baruch, Budhwa and Khatri 2007; Fontes 2007: 285; Ackers and Gill 2008). According to scholars of these phenomena, while the brain drain processes are usually considered to be spontaneous, the brain gain processes are usually organized by governmental programmes, foundations, research labs, and universities. Brain drain ideas came to be regarded as too simplistic when the migration scholars realized that, with the obvious lack of symmetry in this exchange, all partners gain (although to a different extent and in a different sense), and costs, unequally divided, again, are shared by all parties.

While gains for the receiving countries seem to be obvious (various kinds of challenges are being analysed as well, however), it seems to be more interesting to focus on the assumed gains for the sending countries. According to the conceptualizations in terms of "brain circulation", if highly educated people cannot find adequate employment in their homelands, they do not bring any harm to their country when they emigrate. Educating people and letting them emigrate can be considered a rational strategy, as they will send back money, and if they return, bring back their experience and new skills, usually unavailable in the countries of origin. If remaining abroad, they often join global scientific networks via their own diasporas (for the significance of diasporas, old and present, see, e.g., Braziel and Mannur, eds. 2003). Many members of these diasporas support developmental efforts of their countries of origin, engaging in joint projects, investing, and educating (see, e.g., Morano-Foadi 2005; Gokbayak 2009; Castles and Miller 2011; Ivancheva and Gouvrova 2011)

The dates of publication of the above-mentioned sources make it clear that the brain drain controversy has lost none of its significance over the last 50 years. 
In 1997, the quarterly "Science, Technology and Society" published a special issue on "International Mobility of Brains in Science". A similar issue of this journal appeared nearly 20 years later (20/3/2015). We would like to devote a paragraph to the introductory chapter (Gaillard, Gaillard and Krishna 2015). Its authors (co-editors of the issue) mention the pluses and minuses of highly skilled migrations and concentrate on the sending, usually poor, countries. Interestingly, they send some specialists but also receive others from abroad. Circulation of "brains" is considered a "natural" aspect of globalization in which talent and skills are more important than nationality, and many countries wish to actively participate in the process. The gains of the sending countries (as presented above) mostly mean facilitation in the transfer of knowledge and technology, remittances, political and cultural support, and building general support networks. Maintaining the circulation of talents while avoiding negative consequences seems to be tied to two processes: a) balance between the emigration and returns, and b) efficient functioning of diasporas. If these processes are successful, a win-win effect is achieved. One should bear in mind, however, that the state of the world is far from balanced and symmetrical exchange. Many countries suffer from real brain drain problems, because emigrant HSMs do not return and the diasporas do not function efficiently. Emigrants do not come back because the richer receiving countries encourage talented and highly skilled immigrants to stay, and the sending countries cannot afford offers to attract them back. Participation in global fields of research and development results in immigration to poorer countries of very highly qualified and experienced specialists, usually from developed countries, which often means that there are no jobs for domestic scientists and engineers at the early stages of their careers, or even for potential returnees. Returns are socially and culturally difficult. In many cases, they are not an appealing option in economic and political terms. However, there are interesting examples of "successful", even if controversial, strategies, for instance in South Korea, India, Singapore and China. They offer the returnees a career path different than those for the domestic specialists, with higher income and much better working conditions (see, e.g., Lu and Zhang 2015; Song and Song 2015). These policies generate tensions and encourage domestic scientists to emigrate.

Returns of HSM have been a problem for many decades, both in the Global South and in the North (West). About a half of foreign graduate students and $\mathrm{PhD}$ candidates (from all regions) in developed countries intend to remain there when they finish their education and many of them do. Actually, the functioning of many Western research institutes and laboratories would be difficult without them. When they become established in these research centres, laboratories, and universities, and are promoted and become leaders of their own teams, return is even more difficult. Good jobs and well-equipped laboratories are rarely waiting for them. Other, already presented, ways of keeping in touch with the "old country" are chosen more often than returns. 
The vast Portuguese sociological literature on the potential and actual cases of returns of the HSM is very instructive. It documents how painful it is for migrating scientists to return home. It is particularly interesting from the Polish point of view, since the Portuguese economic situation, the system of higher education and research, and the emigration and immigration of academics are all quite similar to those of Poland (for the mobility of Portuguese scientists, see, e.g., Delicado 2010a). Margarida Fontes in 2005 (see 2007) and Ana Delicado in 2007 (see 2009) conducted surveys on the returns and willingness to return of their academic compatriots. She found several interesting tendencies. The Portuguese academics are transmigrants: they are highly mobile, as they move from country to country and between research institutions. Most of them do not even consider a return to their country of origin, at least not in the near future. Those who consider returning are either convinced that it would be very hard to find an adequate job for people with their qualifications, or would go back only if the right kind of employment were available. The older they are and the higher their position in the research structure abroad, the lower their willingness to return and the higher their expectations. Some of these relatively few and relatively young academics who returned to Portugal had unpaid leaves of absence at their own institutions in the country of origin while they worked abroad, so their employers waited for them. The main motivation to return was a willingness to help the country (literature on returning Turks, Germans and Russians presents these motives as well, see, e.g., Laudel 2005; Gokbayrak 2009). This seems to be true motivation in the sense that when abroad, they collaborated with scientists at home as well as with Portuguese scientists abroad. The "diaspora effect" is evident here. However, about a half of those who returned were planning to emigrate again. To sum up these Portuguese studies, we could say that the most important gains from the returns are: transmission of "tacit knowledge" acquired abroad; development at home of new, previously hardly known, fields of research; modification of the scientific culture at home; and internationalization of the Portuguese research area.

\section{References}

Ackers L., Gill B. (2008), Moving People and Knowledge. Scientific Mobility in an Enlarging European Union, Cheltenham, UK \& Northampton, MA USA: Edward Elgar.

Alarcon R. (2007), The free circulation of skilled migrants in North America, in: Pecoud A., de Guchteneire P. (eds.), Migration without Borders. Essays on the Free Movement of People, Paris: UNESCO and Oxford and New York: Berghahn Books, p 243-257.

Andrejuk K. (2017), Czy istnieje zjawisko Lifestyle Migration do Polski? O badaniach przyczyn mobilności migrantów wewnątrzunijnych mieszkających $w R P$, „Studia Migracyjne Przegląd Polonijny" 1 (163), p. 259-283.

Baruch Y., S. Budhwar P.S., Khatri N. (2007), Brain drain: Inclinations to stay abroad after studies, „Journal of World Business” 42, 1, p. 99-112. 
Benson M. (2016), Deconstructing belonging in lifestyle migration: Tracking the emotional negotiations of the British in rural France, "European Journal of Cultural Studies", DOI $10.1177 / 1367549416631554$.

Bielewska A., Jaskułowski K. (2017), Place Belonging in a Mobile World: A Case Study of Migrant Professionals, "Czech Sociological Review" 543, 3, p. 343-367.

Biemann T., Andersen M. (2010), Self-initiated foreign expatriates versus assigned expatriates, "Journal of Managerial Psychology" 25, 4, p. 430-450.

Braziel J.E., Mannur A., eds. (2003), Theorizing Diaspora. A Reader, Malden, MA and Oxford: Blackwell Publishing.

Castles S., Miller M. J. (2003), The Age of Migrations, New York: Guilford Press.

Delicado A. (2009), International mobility of researchers and the circulation of knowledge, mimeo.

Doherty N., Richardson J., Thorn K. (2013), Self-initiated expatriation and self-initiated Expatriates, "Career Development International" 18, 1, p. 97-113.

Fauser M., Voigtländer S., Tuncer H., Liebau E., Faist T., Razum O. (2012), Transnationality and social inequalities of migrants in Germany, Project: "From Heterogeneities to Inequalities". SFB 882 Conference, 20-21 September, Bielefeld, Universität Bielefeld, mimeo.

Fontes M. (2007), Scientific mobility policies: how Portuguese scientists envisage the return Home, "Science and Public Policy" 34, 4, p. 284-298.

Gaillard J., Gaillard A.M., Krishna V.V. (2015), Return from Migration and Circulation of Highly Educated People: The Never-ending Brain Drain, "Science, Technology and Society" 20, 3, p. 269-278.

Gokbayrak S. (2009), Skilled Labour Migration and Positive Externality: The Case of Turkish Engineers Working Abroad, „International Migration” 50, S1, p. 132-150.

Hannerz U. (1996), Transnational Connections. Culture, People, Places, London: Routledge.

Hart D. (2007), Understanding Immigration in a National Systems of Innovation Framework, "Science and Public Policy" 34, 1, p. 45-53.

Ivancheva L., Gourova E. (2011), Challenges for career and mobility of researchers in Europe, "Science and Public Policy" 38, 3, p. 185-198.

Jałowiecki B., Gorzelak G.J. (2004), Brain Drain, Brain Gain, and Mobility: Theories and Prospective Methods, "Higher Education in Europe" XXIX, 3, p. 299-308.

Jaskułowski K. (2017), Indian Middling Migrants in Wroclaw: A Study of Migration Experiences and Strategies, "Asian and Pacific Migration Journal" 26 (2), p. 262-273.

Laudel G. (2005), Migration Currents among the Scientific Elite, "Minerva" 43, p. 377-395.

Loacker B., Sliwa B. (2016), 'Moving to stay in the same place?' Academics and theatrical artists as exemplars of the 'mobile middle', "Organization" 23, 5, p. 657-679.

Lu X., Zhang W. (2015), The Reversed Brain Drain: A Mixed-method Study of the Reversed Migration of Chinese Overseas Scientists, "Science, Technology and Society" 20, 3, p. 279-299.

Morano-Foadi S. (2005), Scientiific Mobility, Career Progression and Excellence in the European Research Area, "International Migration" 43, 3, p. 133-162.

Morawska E. (2009), Badania nad imigracją/etnicznościa w Europie i Stanach Zjednoczonych: Analiza porównawcza, „Studia Migracyjne-Przegląd Polonijny” 1, p. 7-26.

Morawska E. (2013), The Impact of Past and Present Immigrants' Transnational Engagements on Their Home-Country Localities: Exploring an Underinvestigated Aspect of the Transnationalism/Migration Relationship, "Studia Migracyjne-Przegląd Polonijny” 1, p. 7-31.

Mucha J., Łuczaj K. (2018), Polska w świecie „krążących umysłów”. Zagraniczni pracownicy naukowo-dydaktyczni na uczelniach krakowskich, Warszawa: Wydawnictwo Uniwersytetu Warszawskiego. 
Nowicka M. (2005), Transnational Professionals and their Cosmopolitan Universes, Frankfurt and New York: Campus Verlag.

O’Reilly K., Benson M. (2009), Lifestyle Migration: Escaping to the Good Life?, in: Benson M., O’Reilly K. (eds.), Lifestyle Migration: Expectations, Aspirations and Experiences, Aldershot: Ashgate, p. 1-13.

Przytuła S. (2017), Ekspatriacja tradycyjna i samoinicjowana jako formy migracji Transnarodo$w e j$, ,Studia Migracyjne Przegląd Polonijny” 1 (163), p. 285-306.

Richmond A.H. (1994), Global Apartheid. Refugees, Racism, and the New World Order, Toronto at al.: Oxford University Press.

Santos G.G. (2016), Career barriers influencing career success. A focus on academics' perceptions and experiences, „Career Development International” 21, 1, p. 60-84.

Selmer J., Lauring J. (2012), Reasons to expatriate and work outcomes of self-initiated Expatriates, "Personal Review" 41, 5, p. 665-684.

Song H.Z, Soong E. (2015), Why Do South Korea's Scientists and Engineers Delay Returning Home? Renewed Brain Drain in the New Millennium, "Science, Technology and Society" 20, 3, p. 349-368.

Spalding A.K. (2013), Lifestyle Migration to Bocas del Toro, Panama: Exploring Migration Strategies and Introducing Local Implications of the Search for Paradise, "International Review of Social Research" 3, 1, p. 67-86.

Vertovec S. (2009), Transnationalism, London: Routledge. 